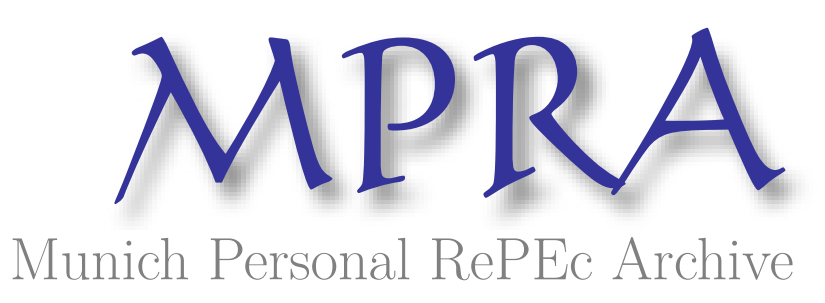

The unintended consequences and challenges of the Basel III Leverage Ratio: supplementary leverage ratios

Ojo, Marianne

North West University

15 January 2015

Online at https://mpra.ub.uni-muenchen.de/61330/

MPRA Paper No. 61330, posted 16 Jan 2015 00:11 UTC 


\title{
The Unintended Consequences and Challenges of the Basel III Leverage Ratio: Supplementary Leverage Ratios
}

\begin{abstract}
The U.S standard leverage ratio, which is not as stringent as the U.S Supplementary Leverage Ratio, did not include Off Balance Sheet exposures - unlike the Basel leverage ratio. Hence the 3\% Supplementary Leverage Ratio was established as part of measures to facilitate the inclusion of Off Balance Sheet exposures in July 2013 - even though many still consider the scope of such inclusion as not being extensive enough - since Secured Financing Transaction Exposures are still excluded.

Furthermore, the Enhanced Supplementary Leverage Ratio increased the 3\% leverage ratio to 5\% (a $2 \%$ buffer) for globally systemic important banks (GSIBs) bank holding companies and $6 \%$ for their banking subsidiaries. In respect of securities financing transaction exposures, however, U.S banks are considered to enjoy competitive advantage, since the exclusion of such exposures still persist - even though it is also argued that recent liquidity coverage and net stable funding ratio provisions should serve to address these exposures - this also being in line with the complementary functions of liquidity standards and leverage ratios within the risk-based capital adequacy framework.
\end{abstract}

As well as contributing to the extant literature on supplementary leverage ratios, this paper will seek to illustrate why calibration between the risk capital adequacy framework, liquidity standards, and Basel leverage ratio is even more important than merely a focus on the relationship between the risk capital adequacy framework and the Basel leverage ratio.

Meanwhile as regards Europe, there are also concerns relating to sovereign credit risks and the "inadequate pricing" of such risks which results in undercapitalisation of banks, as well as potential consequences relating to serious distortions in financial stability whose effects could have repercussions extending beyond the Eurozone and globally. This paper considers two headings which have generated controversial discussions - particularly in respect of Basel III leverage ratio implementation, namely, undercapitalisation of banks and the issue of calibration. It aims to illustrate why these constitute areas which are still in need of redress - even though tremendous efforts have been made to align the Basel III Leverage Ratio with the Supplementary Leverage Ratios. The paper will also demonstrate that whilst there are concerns related to the issue of calibration, certain jurisdictions such as the UK, have also introduced supplementary leverage ratios - as well as considered alternatives to the Basel leverage ratio.

Key Words: supplementary leverage ratios; short term funding; financial stability; OBS exposures; Standardised Approach to Counterparty Credit Risk (SA-CCR);redit conversion factors (CF) 


\title{
The Unintended Consequences and Challenges of the Basel III Leverage Ratio: Supplementary Leverage Ratios
}

\author{
Marianne Ojo ${ }^{1}$
}

\section{A Introduction}

Based on a recent report, ${ }^{2}$ it was highlighted that "the remaining key difference" between the Supplementary Leverage Ratio (SLR) and the Basel III Leverage Ratio had been resolved with an alignment between the two ratios - through the September 2014 Final Rule. Such "key difference" being: how often off- balance sheet exposures are to be calculated.

Whilst the Basel III Leverage Ratio is calculated as the average of the three month end leverage ratios over a quarter, and the Final Rule requires that off balance sheet exposures be calculated as the average of month end balances for the reporting quarter, the requirement for "daily calculation of on-balance sheet exposures remains unchanged”3 in the Final Rule.

Challenges presented by the Supplementary Leverage Ratio from this perspective include the following: ${ }^{4}$

- Many banks being inadequately equipped to generate "fully reconciled transaction level data on a daily basis;

- SLR's tendency to encourage the retention of riskier and high yielding assets through the penalization of non risky, low yielding holdings with "a hefty capital charge” whilst Basel III capital framework and recently finalised U.S Liquidity Coverage Ratio were considered to encourage the retention of less risky assets.

The Supplementary Leverage Ratio has been criticised from various quarters, not only in respect of the above challenges, but also in relation to claims that it would furthermore, provide firms with incentives to engage in the manipulation of data, given its stringent conditions and the consequential competitive disadvantages these firms would be subjected to.

Needless to say, the potential for regulatory capital arbitrage practices and high risk taking levels have constituted some of the most prominent reasons for discrediting the supplementary leverage ratio.

\footnotetext{
${ }^{1}$ Professor, Faculty of Commerce and Administration, North-West University Email: marianneojo@hotmail.com

${ }^{2}$ See PricewaterhouseCoopers, “First Take: Supplementary Leverage Ratios” September 102014 http://www.pwc.com/us/en/financial-services/regulatory-services/publications/first-take-supplementary-leverage-rati o-basel-iii.jhtml

${ }^{3}$ see ibid

${ }^{4}$ ibid
} 
However the subsequent section will seek to illustrate why the introduction of supplementary leverage ratios and enhanced supplementary leverage ratios is now appearing to be the norm in several jurisdictions. Most notable of these reasons relate to the growing realisation that the risk based capital adequacy framework is not adequately calibrated with the Basel leverage framework, as well as the need to avoid scenarios whereby undercapitalisation of banking institutions, as well as non financial institutions could occur.

In addition to the issue of calibration between the risk based capital adequacy framework and the Basel leverage framework, another potential source of undercapitalisation of financial and non financial institution relates to the use of credit conversion factors.

It was expected that the Current Exposure Method would be replaced by the Standardised Approach for Measuring Counterparty Credit Risk exposures (SA-CCR). The conversion of off balance sheet items into credit exposure equivalents were facilitated by the Basel Committee’s January 2014 revised leverage ratio standard. In response to concerns raised by the 2013 June revisions, concerns such as the fact that the leverage ratio's denominator was too large, changes aimed at incorporating a more simplistic and standardized means of measuring exposures were introduced - through the use of the Standardised Approach.

According to the January 2014 revised leverage ratio standard, credit conversion factors (CCFs) as set out in paragraphs 14 - 22 of its Annex, must be applied to notional amounts for purposes of determining the exposure amount of OBS items for leverage ratio.

Hence in highlighting the complications resulting from the measurement and conversion of OBS exposures, it will be demonstrated that the frequency of calculation of such items not only constitutes one of the problematic issues in need of reconciliation, but also the most appropriate mode of calculation.

How are Off Balance Sheet Exposures to Be Calculated?: The Use of Credit Conversion Factors (CCFs) and their Applicability Within the Leverage Ratio Framework

The use of CCFs, as finalised by the Basel Committee's January 2014 Final Standard, has been considered inappropriate since it applies risk weighting factors to a non risk based leverage framework and further it is argued, that the reduction of exposures through CCFs to as little as $10 \%$, could result in the undercapitalisation of banks. 
As well as the opinion shared by Pricewaterhouse Coopers ${ }^{5}$ that U.S regulators are unlikely to reduce the ESLR, many reasons why the fear of undercapitalisation may compel regulators to adhere to the introduced buffers also relate to the inappropriateness and uncertainty inherent with the use of CCFs.

According to $\mathrm{PwC}:^{6}$

- ..the use of CCFs to adjust certain OBS exposures are inappropriate for use in a leverage ratio based framework because they introduce risk factors similar to a risk weighted capital framework - and such use of CCFs undermines the purpose of leverage ratios.

The ensuing section is therefore aimed at explaining why the issue of calibration between the leverage ratio and capital adequacy framework has become so important - in view of the above-mentioned inadequacies of credit conversion factors.

Section A has introduced the Supplementary Leverage Ratio (SLR) from the onset and the rationale lying behind its fore-running implementation in the United States - namely, the need to account for off-balance sheet exposures. It highlights how even though the SLR initially received criticisms, its growing incorporation and application in numerous jurisdictions has been triggered by the realisation that Basel measures, and in particular, the Standardized Approach (SA-CCR) which incorporates the use of credit conversion factors, may not only serve as an inadequate means of measuring and accounting for off balance sheet exposures, but could also result in the undercapitalisation of banks. The introductory section also considers the issue of calibration and the fundamental role this is assuming in ensuring that adequate measures are obtained, as well as closer relationships and links established, between the capital adequacy framework, liquidity and Basel leverage framework.

The review section, section B broadly defines basic concepts, developments relating to the three fundamental regulatory and supervisory tools of the Basel Committee, namely, the capital adequacy ratios, liquidity standards and leverage ratio. It also attempts to explain the rationale behind the introduction of these vital and complementary regulatory tools - culminating with the all important Supplementary Leverage Ratio. From this perspective it will also consider empirical analyses undertaken in the United Kingdom prior to the implementation of recent supplementary ratios.

Section C focuses on initiatives which are currently being undertaken to discourage reliance on short term funding - as well as why greater initiatives should be taken in addressing inadequacies in risk

\footnotetext{
5 PricewaterhouseCoopers, “Regulatory Brief: Basel Leverage Ratios: No Cover For US Banks” January 2014 particularly pages 3 and 4 http://www.pwc.com/en US/us/financial-services/regulatory-services/publications/assets/fs-reg-brief-dodd-frank-ba sel-leverage-ratio.pdf

${ }^{6}$ see ibid at page 4
} 
assessments and management of sovereign bonds in the Eurozone - before such risks trigger systemic consequences for the Eurozone - as well as globally.

Has the "tiger of banking and finance" being transformed into something else or are Basel III efforts to address the deficiencies of the system (which experienced the Financial Crisis) all futile? These constitute some of the issues which the concluding section attempts to address.

\section{B Issue of Calibration Between the Leverage Ratio and Risk Based Capital Framework: Concems Relating to Adequate Buffers}

\section{Literature Review}

\section{Developments Within the Risk Based Capital Adequacy Framework}

"The enhanced Basel II Framework (which includes reforms aimed at increasing the quantity of capital as well as improving the quality of capital), and the macroprudential overlay (together), are referred to as Basel III."7

Under Basel II, the Tier One Capital ratio which banks were required to retain was 4\%. Under Basel III, this has been raised to $6 \%$.

Further, whilst Basel II stipulated a Core Tier One capital ratio of 2\%, this has been increased to 4.5\% under Basel III and comprises of common equity before deductions.

In respect of the capital conservation buffer, Basel III regulations require that banks retain a capital conservation buffer of $2.5 \%$ - bringing total common equity requirements to $7 \%$.

\footnotetext{
${ }^{7}$ For further literature relating to developments within the Basel II and Basel III capital adequacy framework, see Basel Committee on Banking Supervision, 'Capital Requirements and Bank Behaviour: The Impact of the Basel Accord' Basel Committee on Banking Supervision Working Papers April 1999; Basel Committee on Banking Supervision, 'Consultative Paper on a New Capital Adequacy Framework' 3rd June 1999 http://www.bis.org/press/p990603.htm
}

M Ojo, Basel II and the Capital Requirements Directive: Responding to the 2008/09 Financial Crisis (September 2009); M Ojo, Basel III and Responding to the Recent Financial Crisis (September 2010); M Ojo, Basel III - Responses to Consultative Documents, Vital Aspects of the Consultative Processes and the Journey Culminating in the Present Framework (October 2010) and M Ojo, Preparing for Basel IV (Whilst Commending Basel III Part II) (January 2011) Paper presented at the 2011 INFINITI Conference on International Finance, 13 - 14 June 2011, Trinity College Dublin (the 9th INFINITI Conference on International Finance) 13th \& 14th June 2011“'Institutions, Actors and International Finance”. 
In respect of the countercyclical buffer, Basel III regulations stipulate a requirement within a range of $0 \%$ and $2.5 \%$ of "common equity or other fully absorbing capital" to be implemented according to national circumstances.

Both the capital conservation and counter cyclical buffers did not exist under Basel II.

Buffers relating to leverage ratios, as proposed in certain jurisdictions such as the UK and the U.S, are to incorporate common equity Tier One capital. Capital conservation buffers, however, are likely to be introduced subsequently in the UK.

Under Basel III, additional capital requirements have also been stipulated for systemically relevant financial institutions.

According to the Review generated by the Financial Policy Committee, weaknesses associated with risk weightings (internal and standardised) as revealed by the Financial Crisis, include the following:8

1) Since all models are simplifications of reality, they are always 'wrong'. An irreducible amount of modelling uncertainty associated with trying to measure risk persists - even though bad models can be improved, for example by relying on a range of models, better data or more accurate theory.

2) Insufficiently large samples of historical data can lead to significant mis-calibrations in both internal and standardised models if they omit low-probability but large-impact events. ${ }^{9}$

3) Models cannot capture 'unknown unknowns'

4) Since internal bank models are calibrated from the perspective of individual banks and assume risk is exogenous, they do not capture correlations of losses across banks which are at the heart of systemic crises.

\section{Basel III Liquidity Standards - The Liquidity Coverage Ratio and Net Stable Funding Ratio}

The definition of liquidity, as provided by the Bank of International Settlements (BIS), is "the ability of a bank to fund increases in assets and meet obligations as they come due, without incurring unacceptable losses. The fundamental role of banks in the maturity transformation of short-term deposits into long-term loans makes banks inherently vulnerable to liquidity risk, both of an institution-specific nature and that which affects markets as a whole.”

Whilst the Liquidity Coverage Ratio (LCR)'s objective is aimed at „promoting the short-term resilience of the liquidity risk profile of banks by ensuring that banks have an adequate stock of unencumbered high quality assets (HQLA) that can be converted easily and immediately into cash" to meet the liquidity needs of private markets for a 30 calendar day liquidity stress scenario, the Net Stable Funding Ratio (NSFR) is targeted at medium to longer term funding activities of banking institutions.

\footnotetext{
${ }^{8}$ Bank of England, “ Financial Policy Committee’s Review of the Leverage Ratio October 2014 at pg 12

9 "known as "tail events" See ibid
} 
Since the Net Stable Funding Ratio is the ratio which focuses on longer term funding activities of banking institutions, efforts are being made by regulators to encourage less reliance on shorter term funding activities. This being particularly the case since the recent Financial Crisis has demonstrated not only that financial institutions complying with stipulated capital adequacy ratios could still face serious financial distress, but also how quickly a credit crisis could generate into one attributed to liquidity problems.

\section{Basel Leverage Ratio}

A leverage ratio is defined as the capital measure divided by the exposure measure of a firm's assets. The Basel III Leverage Ratio is defined as the Capital Measure (the numerator) divided by the Exposure Measure (the denominator), with this ratio expressed as a percentage and with the basis of calculation being the average of the three month-end leverage ratios over a quarter. ${ }^{10}$

Further, according to the Financial Policy Committee, a leverage ratio is an 'indicator of a firm's solvency, and is the ratio of its capital relative to a gross measure of its exposures or assets. As assets have to be funded either by capital or debt, the lower a bank's leverage ratio, the more it relies on debt rather than capital to fund its assets."11

As is the case with the two liquidity standards which are intended to serve as complementary measures to the risk-based capital adequacy framework, the Basel III Leverage Ratio was established by the Basel Committee in December 2010 as a non-risk based measure which is intended to serve as a supplement to the Basel risk based capital framework. The merits of the Leverage Ratio as a supplement to the risk based capital adequacy framework include: ${ }^{12}$ i) Its constraint of the build-up of

\footnotetext{
${ }^{10}$ Basel Committee on Banking Supervision, Consultative Document Revised Basel III Leverage Ratio Framework and Disclosure Requirements at page 5 of 22 http://www.bis.org/publ/bcbs251.pdf

${ }^{11}$ Bank of England, “ Financial Policy Committee’s Review of the Leverage Ratio October 2014 at pg 9

"In the UK, the definition for the exposure measure, the denominator of the leverage ratio, is to be aligned with the definition agreed by the BCBS, as implemented in European law.

In relation to the capital measure, the numerator of the leverage ratio - additional Tier 1 (AT1), capital instruments of sufficient quality to convert to common equity Tier 1 (CET1) capital on a going concern basis would be permitted to comprise up to $25 \%$ of the minimum requirement." see ibid at page 6

${ }^{12}$ Basel Committee on Banking Supervision, Discussion Paper 'The Regulatory Framework: Balancing Risk Sensitivity, Simplicity and Comparability“ July 2013 Bank for International Settlements Publications at page 16 Further, according to the FPC, the rationale for using a leverage ratio as a part of regulation is that in environments which are characterised by complexity, small samples and uncertainties, simple indicators often outperform more complex ones. see Bank of England, “ Financial Policy Committee’s Review of the Leverage Ratio October 2014 at pg 13 and also Haldane and Madouros (2012) and Aikman et al (2014). Aikman, D et al (2014), 'Taking uncertainty seriously: simplicity versus complexity in financial regulation', Bank of England Financial Stability Paper No. 28, available at www.bankofengland.co.uk/research/Documents/fspapers/fs_paper28.pdf.
} 
leverage in the banking sector - which the risk based regime is not equipped to address; ii) Through a non-risk based „backstop“ which ultimately serves to protect against model risk, and the reduction of capital requirements, its reinforcement of risk based requirements; iii) Its role as a standardized measure that investors and counterparties can use in making comparisons between banks over a period of time; iv) The establishment by certain academics that the leverage ratio is a ,statistically significant“ predictor of potential bank failures.

The U.S standard leverage ratio, which is not as stringent as the Supplementary Leverage Ratio, did not include Off Balance Sheet exposures - unlike the Basel leverage ratio. Hence the 3\% Supplementary Leverage Ratio was established as part of measures to facilitate the inclusion of Off Balance Sheet exposures in July 2013 - even though many still consider the scope of such inclusion as not being extensive enough - since Secured Financing Transaction Exposures are still excluded. Furthermore, the Enhanced Supplementary Leverage Ratio increased the 3\% leverage ratio to 5\% (a 2\% buffer) for globally systemic important banks (GSIBs) bank holding companies and $6 \%$ for their banking subsidiaries. In respect of securities financing transaction exposures, however, U.S banks are considered to enjoy competitive advantage, since the exclusion of such exposures still persist - even though it is also argued that recent liquidity coverage and net stable funding ratio provisions should serve to address these exposures - this also being in line with the complementary functions of liquidity standards and leverage ratios within the risk-based capital adequacy framework.

According to the Financial Policy Committee, supplementary leverage ratio buffers, which would be applied to systemically important firms (G-SIBs and other major domestic UK banks and building societies, including ring-fenced banks), would be set at $35 \%$ of the corresponding risk-weighted systemic risk buffer rates for these firms. ${ }^{13}$

Another justification and plausible explanation relating to why certain jurisdictions, such as the United Kingdom, may have considered the need to introduce supplementary ratios - may also be intrinsically linked to the rationale provided by United States regulators to introduce not only supplementary leverage ratios, as regards the eight globally systemically important banks (G-SIBs), ${ }^{14}$ but also enhanced supplementary leverage ratios - the need to avert possible undercapitalisation which could result to serious distortions within the financial system as a whole - given the systemic relevance of such banks.

Concerns have been expressed in relation to the Basel leverage ratio not being as well calibrated to accommodate such buffers as those which exist within the risk based capital adequacy framework.

\footnotetext{
13 Bank of England, “ Financial Policy Committee's Review of the Leverage Ratio October 2014 at pg 6

"Such $35 \%$ conversion factor preserves the relationship between the $3 \%$ minimum leverage requirement and the $8.5 \%$ Tier 1 risk-weighted capital requirement.” see ibid

${ }^{14}$ The eight globally systemically important banks in the U.S, identified as G-SIBs by the Financial Stability Board, are: Bank of America Corporation, The Bank of New York Mellon Corporation, Citigroup Inc., Goldman Sachs Group, Inc., JP Morgan Chase \& Co., Morgan Stanley, State Street Corporation and Wells Fargo \& Company. See Financial Stability Board, Update of Group of Global Systemically Important Banks (G-SIBs) (Nov. 1, 2012)

http://www.financialstabilityboard.org/publications/r_121031ac.pdf
} 
According to the Bank of England's recent report on the Financial Policy Committee (FPC)'s Review of the Basel Leverage Ratio, ${ }^{15}$

- In order to maintain the relationship between the risk-weighted capital ratio and leverage ratio regimes, the FPC is requesting a direction power over a supplementary leverage ratio buffer for these systemically important firms. This power would also enable the FPC to advance its 'too big to fail' objective.

Furthermore, in recommending a review on the leverage ratio for the UK banking system, the following key considerations were highlighted:

- A minimum leverage ratio requirement, to remove or reduce systemic risks attributable to unsustainable leverage in the financial system.

- A supplementary leverage ratio buffer, to remove or reduce systemic risks attributable to the distribution of risk within the financial sector.

- A countercyclical leverage ratio buffer, to remove or reduce systemic risks attributable to credit booms - periods of unsustainable credit growth in the economy.

Such an approach, in the Financial Policy Committee's opinion, would not only "see the leverage ratio fully integrated into the current regulatory structure, but also "play a complementary role to the risk-weighted capital ratio for the regulation both of systemically important firms and in times of high system-wide risk."

According to a report by the Federal Reserve, the following provide rationale for the need for revisions to the Basel Leverage Ratios:.$^{17}$

\footnotetext{
${ }^{15}$ See Bank of England, “ Financial Policy Committee’s Review of the Leverage Ratio October 2014 at page 16

“The Financial Policy Committee of the Bank of England issued recommendations for enhanced leverage ratio requirements to apply to UK global systematically important banks, and other major domestic UK banks and building societies.” See Shearman \& Sterling LLP, “Enhanced Leverage Ratios for UK Financial Institutions” December 2014 at page 1

http://www.shearman.com/ /media/Files/News Insights/Publications/2014/12/Enhanced-Leverage-Ratios-for-UK-Fina ncial-Institutions-FIA-120114.pdf

${ }^{16}$ see ibid at page 15

${ }^{17}$ Federal Reserve, 'Regulatory Capital Rules: Regulatory Capital, Enhanced Supplementary Leverage Ratio Standards for Certain Bank Holding Companies and their Subsidiary Insured Depository Institutions' 2013 pages 16 and 17
} 
- BCBS's approach for determining the minimum level of the Basel III leverage ratio was different than the calibration approach described above for the risk-based capital ratios.

- The BCBS used the most loss-absorbing measure of capital, common equity tier 1 capital, as the basis for calibration for the risk-based capital ratios, but not for the Basel III leverage ratio. In addition, the BCBS did not calibrate the minimum Basel III leverage ratio to meet explicit loss absorption and market confidence objectives as it did in calibrating the minimum risk-based capital requirements and did not implement a capital conservation buffer level above the minimum leverage ratio.

In acknowledging the issues relating to calibration, the Basel Committee chairman stated in February 2014 that " only now that we have an agreed measure of leverage exposure, can the Committee begin to turn to the issue of calibration,

and,

the relationship between the leverage ratio and the risk based framework.”

\section{Empirical Studies Relating to Capital Adequacy and Leverage Ratio Frameworks}

Having considered the capital and leverage frameworks, one vital difference between both frameworks is namely, whereas "risk-weighted capital ratios differentiate capital requirements according to estimates of the relative riskiness of different types of assets, a leverage ratio weights all assets equally."18

In comparison to the capital adequacy framework, however, less empirical evidence exists to bolster various related claims since the Basel leverage ratio was only just recently introduced in 2010.

According to the Financial Policy Committee (FPC), the relative simplicity of the leverage ratio might make it more readily understood by market participants and more comparable across firms than risk-weighted measures or stress test outputs. ${ }^{19}$

Empirical evidence relied upon by the FPC to supports this view include the following: ${ }^{20}$

- First, leverage ratios fell in the United Kingdom and several other countries in the run-up to the crisis, while capital adequacy ratios based on risk weights were broadly stable. The leverage ratio attached much more significance to the rapid expansion in intra-financial exposures which turned out to be a significant source of losses in the height of the crisis.

- Second, a number of studies have found that the leverage ratio was a better predictor of bank failure during the crisis than the risk-weighted capital ratio.

- $\quad$ Third, recent IMF research paper which shows that banks with higher leverage ratios (ie less leverage) in the run-up to the recent financial crisis reduced lending less than banks with lower

\footnotetext{
${ }^{18}$ Bank of England, “ Financial Policy Committee’s Review of the Leverage Ratio October 2014 at pg 10

${ }^{19}$ see ibid at page 13

${ }^{20}$ ibid at page 14
} 
leverage ratios (ie higher leverage), even when taking into account dependence on non-deposit funding." 21

\section{Liquidity Risk Management: Financial Stability with Longer Term Funding and Risk Weighting in Relation to Sovereign Bonds}

\section{The Systemic Impact of Liquidity Risks}

As previously highlighted under section BII, "The fundamental role of banks in the maturity transformation of short-term deposits into long-term loans makes banks inherently vulnerable to liquidity risk, both of an institution-specific nature and that which affects markets as a whole.”

Having considered, the issue of calibration between the risk based capital adequacy framework and the Basel leverage ratio, we now focus on the third vital component in the equation - namely, liquidity standards. The importance of addressing crises relating to liquidity is not only illustrated by the recent Financial Crisis whereby it has been highlighted that what indeed started as a credit crises, converted later on into an illiquidity crisis. ${ }^{22}$

Wolf emphatically remarks that, "given the poor performance in the run up to the crisis and doubts about the workability of the new doctrines”, that it is questionable whether and if Basel III will succeed ${ }^{23}$ He adds that, in addressing the questions relating to the workability of Basel III, the focus will not only be on the attempt to rescue a system that "in its essence, will remain like the one that went into crisis, and that the focus should be on taming the tiger of banking and finance and not turn it into another animal.”

Further, according to Valladares, the liquidity standard is divided into short and long term buffers - a means of ensuring that banks are liquid. ${ }^{24}$ The focus on financial stability through incentives aimed at placing less reliance on short term funding is also illustrated through recent proposals and rules introduced by the Federal Reserve in the efforts to address further issues relating to calibration.

\footnotetext{
${ }^{21}$ According to the FPC, "this result was not clear when the authors used risk-weighted capital ratios rather than leverage ratios.”

${ }^{22}$ MR Valladares “What Awaits Banks After the Leverage Ratio?” http://dealbook.nytimes.com/2014/04/09/what-awaits-banks-after-the-leverage-ratio

${ }^{23}$ M Wolf, The Shifts and the Shocks: What We've Learned - and Have Still to Learn” see particularly prologue 2014 Penguin Press New York

${ }^{24}$ MR Valladares "What Awaits Banks After the Leverage Ratio?”

http://dealbook.nytimes.com/2014/04/09/what-awaits-banks-after-the-leverage-ratio
} 
With respect to the calibration of surcharges, it was highlighted that such calibration would: ${ }^{25}$

- generally be higher than those applicable to the eight covered U.S. banks under the international standard, and the formula by which applicable surcharges would be calculated would directly take into account the reliance of each firm on short-term wholesale funding.

\section{Discouraging Incentives Towards Short-Term Funding}

Hence the efforts being made to discourage reliance on short-term funding is demonstrated. These steps and initiatives also demonstrate commitment towards towards the enhancement of the micro-prudential framework whereby liquidity risk management efforts would be facilitated - as well as further consolidation of the macro-prudential outlay which embodies Basel III.

Reasons highlighted for adopting such a different approach as indicated in the statement are as follows: ${ }^{26}$

with respect to calibration, surcharge levels for most of the eight banks would be higher under the proposal than those required by the Basel standard, and likely meaningfully higher for some of the firms. The approach to calibration being developed in cooperation with other Basel Committee members as a means of determining the additional capital necessary to equalize the probable systemic impact from the failure of a systemically important bank as compared to the probable systemic impact from the failure of a large, but not systemically important, bank holding company.

- Fact that reliance on short-term wholesale funding is among the more important determinants of the potential impact of the distress or failure of a systemically important financial firm on the broader financial system and that the surcharge formula developed by the Basel Committee does not directly take into account reliance on short-term wholesale funding.

- Inclusion of reliance on short-term wholesale funding as one of five factors in the systemic significance formula is intended principally as a means for assuring the resilience of large firms that are in fact dependent on such funding.

As well as its primary aim of "preventing or mitigating risks to financial stability", ${ }^{27}$ section 165 of the Dodd Frank $\mathrm{Act}^{28}$ specifically stipulates enhanced leverage requirements as a required prudential standard whilst additional authorised standards include contingent capital requirements, enhanced public

\footnotetext{
${ }^{25}$ D Tarullo, “ Opening Statement by Governor Daniel K. Tarullo before Federal Reserve Board” http://www.federalreserve.gov/newsevents/press/bcreg/tarullo-statement-20141209.htm

${ }^{26}$ ibid

${ }^{27}$ See section 165(1) of the Dodd Frank Act

28 "Enhanced Supervision and Prudential Standards for Non-Bank Financial Companies Supervised by the Board of Governors and Certain Bank Holding Companies”
} 
disclosures, short term debt limits and other prudential standards as prescribed by the Board of Governors.

According to the Joint Notice of Proposed Rule-Making by the OCC, Treasury, Federal Reserve and the FDIC, ${ }^{29}$ the Dodd Frank Act not only directs the Board to implement enhanced prudential standards that consolidate existing micro-prudential supervision and regulation of individual companies, but also that which incorporates macro-prudential considerations in order to reduce threats posed by affected companies - thereby reducing the threat to financial stability.

Acharya argues that current under-capitalisation of Eurozone banks against sovereign risk exposures would likely subject the rest of economies world-wide to "credit crunches or substantially higher cost of borrowing” than necessary. ${ }^{30}$ He further adds, that whilst Eurozone sovereign bonds may be liquid or "swappable" through the ECB, that such bonds are presently highly credit risky - with a question of how Eurozone banks were to increase their holdings of liquid assets at a time when "candidate assets" were considerably credit risky. ${ }^{31}$

\section{Conclusion: Taming the Systemics Risks and Contagion within the Financial Sector}

In "taming the tiger of banking and finance and not turning it into another animal", recourse should also be made to the rationale for financial regulation - such rationale consisting of the embodiment of two issues, namely:

The need to address, firstly, asymmetric information, and secondly, the main focus of this paper, the need to address and prevent the dissipation of system wide risks which would pose serious threats and distortions to financial stability. The paper has also highlighted Basel III's focus on macro prudential regulation as a means of further addressing systemic contagion.

\footnotetext{
29 "Regulatory Capital Rules: Regulatory Capital, Enhanced Supplementary Leverage Ratio Standards for Certain Bank Holding Companies and their Subsidiary Insured Depository Institutions.” http://www.federalreserve.gov/newsevents/press/bcreg/bcreg20130709a1.pdf

${ }^{30}$ V V Acharya, "The Dodd-Frank Act and Basel III Intentions, Unintended Consequences, Transition Risks, and Lessons for India" at page $35 \mathrm{He}$ argues that "a significantly problematic issue with Basel III's specific implementation of liquidity risk management is whether the risk weights on government bonds are suitably calibrated for the emerging sovereign credit risk in European zone countries, which imply that many securities which would traditionally have been both liquid and safe, are liquid now (due to central bank collateral qualification) but significantly credit risky.”

${ }^{31}$ ibid at page 36
} 
In addressing possibilities of contagion of such systemic risks, as well as disruptions to the financial system, the focus on globally systemically important banks (G-SIBs), as well as the need to curb effects of "too big to fail" institutions, has been a prominent feature throughout the consideration linked to recent efforts being undertaken by regulators across several jurisdictions.

From this perspective, such efforts and focus are to be commended. Whether the financial system remains the same as that which existed prior to the occurrence of the recent Financial crisis is debatable - this being the case having due consideration to the new Basel Framework - as well as the introduction of supplementary leverage ratios and calibration measures aimed at addressing such a framework. 


\section{References}

Acharya, V V “The Dodd-Frank Act and Basel III Intentions, Unintended Consequences, Transition Risks, and Lessons For India ” 2014

Bank of England, “ Financial Policy Committee’s Review of the Leverage Ratio October 2014

Basel Committee on Banking Supervision, Discussion Paper 'The Regulatory Framework: Balancing Risk

Sensitivity, Simplicity and Comparability“ July 2013 Bank for International Settlements Publications

Basel Committee on Banking Supervision, 'Capital Requirements and Bank Behaviour: The Impact of the Basel Accord' Basel Committee on Banking Supervision Working Papers April 1999

Basel Committee on Banking Supervision, 'Consultative Paper on a New Capital Adequacy Framework' 3rd June 1999 http://www.bis.org/press/p990603.htm

Federal Reserve, 'Regulatory Capital Rules: Regulatory Capital, Enhanced Supplementary Leverage Ratio Standards for Certain Bank Holding Companies and their Subsidiary Insured Depository Institutions'

Financial Stability Board, Update of Group of Global Systemically Important Banks (G-SIBs) (Nov. 1, 2012)

http://www.financialstabilityboard.org/publications/r 121031ac.pdf

Ojo, M Basel II and the Capital Requirements Directive: Responding to the 2008/09 Financial Crisis (September 2009)

Ojo, M Basel III and Responding to the Recent Financial Crisis(September 2010

Ojo, M Preparing for Basel IV (Whilst Commending Basel III Part II) (January 2011) Paper presented at the 2011 INFINITI Conference on International Finance, 13 - 14 June 2011, Trinity College Dublin (the 9th INFINITI Conference on International Finance) 13th \& 14th June 2011"Institutions, Actors and International Finance”.

PricewaterhouseCoopers, “First Take: Supplementary Leverage Ratios” September 102014 http:/www.pwc.com/us/en/financial-services/regulatory-services/publications/first-take-supplementary-l everage-ratio-basel-iii.jhtml 
PricewaterhouseCoopers, "Regulatory Brief: Basel Leverage Ratios: No Cover For US Banks” January 2014 particularly

http:/www.pwc.com/en US/us/financial-services/regulatory-services/publications/assets/fs-reg-brief-do dd-frank-basel-leverage-ratio.pdf

Shearman \& Sterling LLP, “Enhanced Leverage Ratios for UK Financial Institutions” December 2014

Tarullo D , “ Opening Statement by Governor Daniel K. Tarullo before Federal Reserve Board” http:/www.federalreserve.gov/newsevents/press/bcreg/tarullo-statement-20141209.htm

Valladares MR“What Awaits Banks After the Leverage Ratio?”

http:/dealbook.nytimes.com/2014/04/09/what-awaits-banks-after-the-leverage-ratio

Wolf M, The Shifts and the Shocks: What We've Learned - and Have Still to Learn” see particularly prologue 2014 Penguin Press New York 